\title{
Seed Transmission of Cylindrocladium parasiticum in Peanut
}

\author{
B. L. Randall-Schadel, Seed Pathologist, Plant Industry Division, North Carolina Department of Agriculture and \\ Consumer Services, Raleigh 27611-7647; and J. E. Bailey, Professor, and M. K. Beute, Professor Emeritus, De- \\ partment of Plant Pathology, North Carolina State University, Raleigh 27695-7616
}

\begin{abstract}
Randall-Schadel, B. L., Bailey, J. E., and Beute, M. K. 2001. Seed transmission of Cylindrocladium parasiticum in peanut. Plant Dis. 85:362-370.

Seedborne Cylindrocladium parasiticum has been reported in peanuts and the possibility of seed transmission postulated; however, seed transmission has not been documented. Cinnamon brown speckles on peanut testae were correlated with isolation of C. parasiticum. Microscopy indicated that seed were colonized by cinnamon brown colored hyphae and microsclerotia interspersed in and on lightened areas of testa. Speckled seed from commercial seed lots (cultivars NC 7, NC 10C) were planted, with or without a chemical seed treatment (1992, captan + carboxin + dicloran [45:18:15\% of product]; 1993 to 1995 , captan + PCNB + carboxin [45:15:10\% of product]), in fumigated fields with no history of peanut production. Asymptomatic seed from noninfested seed lots (cultivar NC-V 11 or NC 7) were checks for soilborne inoculum. C. parasiticum was isolated from all symptomatic seed lots prior to planting (percentage ranged from 4 to $45 \%$ ) but was not isolated from asymptomatic seed. Seed transmission occurred from seed both with chemical seed treatment $(0.25$ to $2.75 \%)$ and without seed treatment $(0.25$ to $6.0 \%)$, but not in all years. Asymptomatic seed planted $2.5 \mathrm{~cm}$ from speckled seed increased the number of plants with Cylindrocladium black rot from two- to sixfold, illustrating the ability of disease to spread from colonized seed to uninfected plants. It was concluded that seed transmission of $C$. parasiticum is an important means by which this disease is spread within the seed industry.
\end{abstract}

Additional keywords: Calonectria crotalariae, Calonectria ilicicola, Cylindrocladium crotalariae, groundnut, metam sodium

Cylindrocladium parasiticum Crous, Wingefield, and Alfenas (=C. crotalariae (Loos) Bell \& Sobers) Teleomorph = Calonectria ilicicola Boedijin \& Reitsma (=C. crotalariae (Loos) Bell \& Sobers), the causal agent of Cylindrocladium black rot $(\mathrm{CBR})$ of peanuts, is a soilborne pathogen locally spread as microsclerotia in soil and plant debris. Soil movement on equipment can redistribute microsclerotia within and between fields (13). Plant debris blown into the air during combining can be carried by wind to other fields (31). Birds have been implicated in disseminating the pathogen by ingesting infected peanuts and depositing the microsclerotia in droppings (9).

Dissemination by seeds has been investigated $(11,21,23)$. A species of Cylindrocladium was isolated from peanut seeds and pods produced in Puerto Rico as early as 1969 (8), although subsequent attempts to isolate $C$. parasiticum from seed by the same researchers failed (7). Later, $C$. parasiticum was shown to be seedborne, and

Corresponding author: B. L. Randall-Schadel E-mail: Betsy.RandallSchadel@ncmail.net

Accepted for publication 20 December 2000.

Publication no. D-2001-0212-03R

(C) 2001 The American Phytopathological Society symptomatic seeds had a higher frequency of infection than asymptomatic seeds (23). Symptoms on testae reported to be associated with seed infection of this fungus have been described variously as "stippling," in the original description of the disease by Bell and Sobers (3), "flecked" (15), "dark discolored," and discolored with lesions $(11,21,23)$. Johnson (11) noted that the number of severely diseased pods left in the field after harvest added inoculum to the field and suggested that infected seed may serve as inoculum for long-distance dispersal.

Seed transmission of $C$. parasiticum in peanut had been dismissed $(7,30)$ or was considered a remote possibility with currently available seed treatments (23). Inconsistencies in the terminology describing symptoms of seed infection $(3,11,21,23)$, early difficulties associated with isolating C. parasiticum from seed (7), and low transmission rates contributed to doubts about the epidemiological significance of seed transmission. In spite of a description of symptomatic seed by Bell and Sobers (3), subsequent work focused on dark, small seed as the main source of seedborne C. parasiticum. Rowe et al. (30) dismissed seed transmission based on work by Garren and colleagues (7) and on a survey of cultural practices used in the 40 North Carolina peanut fields identified with CBR in 1972. No relationships between disease occurrence, cultivars available, planting date, pesticide use, crop rotational patterns, or basic cultural practices were detected with the survey. Rowe et al. (30) examined dispersal of microsclerotia, noting that these propagules could have a role in shortdistance spread through windblown debris and soil, but also noting that this dispersal mechanism could not explain the longrange spread of $C$. parasiticum that had occurred. Porter and Mozingo (21) considered seed transmission rare and seed treatment an adequate control measure for seedborne $C$. parasiticum. However, $C$. parasiticum was detected in several countries on three continents $(3,7,8,11,14,23$, $29,30,32$ ) during a 15 -year period, and the disease often appeared in the greenhouse and in previously uninfested fields. The movement of $C$. parasiticum through the seed trade was explained by other dispersal mechanisms, and the currently unpredictable nature of seed transmission was overlooked. Speckled seed were believed to be a threat to the Australian peanut industry, and pictures of peanuts with this symptom were displayed in conditioning facilities to aid in hand sorting these seed from the seed supply in the mid-1980s (J. E. Bailey, personal communication after $\mathrm{K}$. Middleton [deceased]).

Although this pathogen has been demonstrated to be seedborne and seed transmission has been suggested, it has not been documented. The rate of seed transmission was anticipated to be low, and to enhance the ability to detect seed transmission, seed symptomatic of infection by the pathogen were used. This study was initiated to determine if seed transmission was occurring in the field by identifying and using seed symptomatic of infection by $C$. parasiticum.

\section{MATERIALS AND METHODS}

Symptomatology and pathogen isolations. Three cultivars of peanut, NC 9, NC 10C, and NC-V 11, were planted May 1991 in fumigated and nonfumigated plots in a field naturally infested with $C$. parasiticum in Bertie County, NC. NC 9 and NC-V11 are susceptible to CBR, and NC $10 \mathrm{C}$ is partially resistant (16). Metam sodium $(35.5 \mathrm{~kg}$ a.i./ha, Vapam 2.16F, Amvac Chemical Corporation, Los Angeles, CA) was applied to plots 2 weeks before planting. The fumigant was injected to a depth of $25 \mathrm{~cm}$ using a single shank per row. Between-row spacing was $0.9 \mathrm{~m}$, and plots were $15.2 \mathrm{~m}$ long. Cultivar and fumi- 
gation treatment combinations were arranged in a randomized complete block design with four replications. The number of row segments $30.5 \mathrm{~cm}$ long with a plant showing symptoms of CBR was recorded before digging. After harvest, pods were dried to $9 \%$ moisture, placed in mesh bags, and stored in an unheated building. Approximately 300 pods from each plot were hand-shelled and screened over a $19 \times 5.95$ $\mathrm{mm}$ slotted screen. Two hundred seed remaining on the screen were arbitrarily separated into two 100-seed subsamples and visually assessed for nine categories of testal symptoms (Table 1). Seeds from one subsample were plated in a medium selective for $C$. parasiticum (20). The medium was modified to facilitate submersion of the seeds by using $0.5 \%$ agar. A second subsample was dipped in a dicloran suspension (3.3 g a.i./liter distilled water, Botran 75 W, TUCO, Division of DuPont Co., Kalamazoo, MI) for 2 min with continuous gentle agitation, drained; dipped 1 min in $0.52 \% \mathrm{NaOCl}$, drained; rinsed 1 min in sterile distilled water, drained; allowed to air dry in a laminar flow hood; and plated in the medium. The dicloran$\mathrm{NaOCl}$ dips were used as a treatment to prevent growth of Rhizopus species, which interfered with detection of viable $C$. parasiticum from peanut seed. C. parasiticum presence or absence was recorded for each seed after incubation for 7 days at room temperature under continuous fluorescent light. The number of positive isolations was analyzed with a general linear models procedure (SAS Institute, Cary, NC). Soil

Table 1. Symptoms on testae of peanut seed harvested from a field heavily infested with Cylindrocladium parasiticum

\begin{tabular}{|c|c|c|}
\hline $\begin{array}{l}\text { Symptom } \\
\text { category }^{\mathrm{a}}\end{array}$ & Symptom description & $\begin{array}{l}\text { Distribution of } \\
\text { symptom on testae }\end{array}$ \\
\hline Speckled & $\begin{array}{l}0.1 \text { to } 0.6 \times 0.1 \text { to } 0.4 \mathrm{~mm} \text { "Cinnamon Brown" to "Mars } \\
\text { Brown" to "Russet Brown" dots or flecks, the larger of } \\
\text { which appear to be a coalescence of smaller dots ( } 0.05 \text { to } \\
0.25 \times 0.003 \text { to } 0.15 \mathrm{~mm} \text { ) and adjacent testa is lighter in } \\
\text { coloration than asymptomatic testa }\end{array}$ & $\begin{array}{l}\text { Speckles clustered } \\
\text { on part or all of the } \\
\text { testa }\end{array}$ \\
\hline Rose & 0.1 to $0.6 \times 0.1$ to $0.4 \mathrm{~mm}$ rose colored dots or flecks & $\begin{array}{l}\text { Often clustered at } \\
\text { apical end }\end{array}$ \\
\hline Blotched & $\begin{array}{l}\text { Round to irregular areas that are slightly lighter than no r- } \\
\text { mal testal color and highly variable in size }\end{array}$ & Not specific \\
\hline Dark brown ${ }^{\mathrm{b}}$ & $\begin{array}{l}\text { General dark brown discoloration, usually over the whole } \\
\text { testa }\end{array}$ & Usually whole testa \\
\hline Light brown ${ }^{b}$ & $\begin{array}{l}\text { General light brown discoloration, usually over the whole } \\
\text { testa; color often same as area between speckles on } \\
\text { speckled seed }\end{array}$ & Usually whole testa \\
\hline Vein & $\begin{array}{l}\text { Rose, "Cinnamon Brown," "Mars Brown," or "Russet } \\
\text { Brown" flecks or dots only along veins }\end{array}$ & Along veins on testa \\
\hline Shriveled $^{\mathrm{c}}$ & $\begin{array}{l}\text { Testa normal to slightly lighter in coloration but testa and } \\
\text { cotyledons shrunken and wrinkled }\end{array}$ & Usually whole testa \\
\hline Injured $^{c}$ & $\begin{array}{l}\text { Normally colored areas that are damaged by insect fee d- } \\
\text { ing or mechanical damage }\end{array}$ & Variable \\
\hline None $^{c}$ & Normal coloration of testa & Whole testa \\
\hline
\end{tabular}

treatment, seed disinfestation, and visual category (symptom classification) effects and their interactions were included in the model. Visual category was treated as an independent variable in the analysis.

Speckled seed were collected in 1999 at digging, and after drying and storage they were fixed in glutaraldehyde and prepared for scanning electron microscopy as per Young and Schadel (35). Speckled seed were also collected after drying and storage and compared to a standard color reference to note color ranges of that symptom (28).

Seed survey. Seed were collected in 1993 from 62 seed lots at three commercial seed shelling plants in the North CarolinaVirginia peanut growing region. The 62 samples included the eight cultivars VC 1, NC 6, NC 7, NC 9, NC 10C, NC-V 11, VA-C 92R, and Florigiant; the proportion of each cultivar sampled was based on the number of acres planted. Samples were collected by probing storage bins of seed prior to the application of seed treatment. A riffle divider was used to take two 500-g subsamples to determine the variation within a sample. Seeds in subsamples were weighed, and the speckled seeds were removed, weighed, and counted.

Seed transmission in the field. Plots 15 $\mathrm{m}$ long were established in fields of Onslow loamy fine sand with no history of peanut culture at the Horticultural Crops Experiment Station, Castle Hayne, NC. To further ensure that no $C$. parasiticum was present, raised beds were commercially fumigated with methyl bromide + chloropicrin (98:2\% product) at $224 \mathrm{~kg} / \mathrm{ha}$ with two curved shanks to a depth of $25 \mathrm{~cm}$ and covered with black plastic (Riddick Fumigants, Williamson, NC) during the fall before the seed were planted in the spring. In 1992, immediately prior to planting, a spacing wheel (Riddick Fumigants) was used to mechanically punch $100,5.1 \times 2.5$ $\mathrm{cm}$ holes through the plastic on each bed to a depth of $7.6 \mathrm{~cm}$ in two $15-\mathrm{m}$ rows 30.5

Table 2. Number of peanut seed from three cultivars exhibiting various symptoms and the proportion of the seed in each category yielding positive isolations of Cylindrocladium parasiticum

\begin{tabular}{|c|c|c|c|c|c|c|}
\hline \multirow{3}{*}{$\begin{array}{l}\text { Visual category } \\
\text { (symptom classifi- } \\
\text { cation) }\end{array}$} & \multicolumn{6}{|c|}{ Peanut cultivar } \\
\hline & \multicolumn{2}{|c|}{ NC 9} & \multicolumn{2}{|c|}{ NC 10C } & \multicolumn{2}{|c|}{ NC-V 11} \\
\hline & $\begin{array}{l}\text { No. of seed with } \\
\text { symptom }^{\mathrm{a}}\end{array}$ & $\begin{array}{l}\text { Proportion with } \\
\text { viable } \mathbf{C P}^{\mathrm{b}}\end{array}$ & $\begin{array}{l}\text { No. of seed with } \\
\text { symptom }^{\mathrm{a}}\end{array}$ & $\begin{array}{l}\text { Proportion with } \\
\text { viable } \mathrm{CP}^{\mathrm{b}}\end{array}$ & $\begin{array}{l}\text { No. of seed with } \\
\text { symptom }^{\mathrm{a}}\end{array}$ & $\begin{array}{l}\text { Proportion with } \\
\text { viable } \mathbf{C P}^{\mathrm{b}}\end{array}$ \\
\hline None & 484 & 0.02 & 454 & 0.02 & 402 & 0.04 \\
\hline Speckled & 97 & 0.32 & 45 & 0.53 & 99 & 0.41 \\
\hline Blotched & 600 & 0.07 & 622 & 0.02 & 614 & 0.06 \\
\hline Rose & 118 & 0.05 & 132 & 0.07 & 146 & 0.10 \\
\hline Dark brown & 15 & 0.07 & 6 & 0.00 & 4 & 0.00 \\
\hline Light brown & 20 & 0.00 & 23 & 0.04 & 32 & 0.17 \\
\hline Vein & 139 & 0.15 & 176 & 0.05 & 165 & 0.10 \\
\hline Shriveled & 119 & 0.03 & 120 & 0.03 & 134 & 0.03 \\
\hline Injured & 8 & 0.25 & 22 & 0.05 & 4 & 0.00 \\
\hline Total & 1,600 & 0.07 & 1,600 & 0.04 & 1,600 & 0.08 \\
\hline
\end{tabular}

${ }^{a}$ Number of seed within each category from a total of 1,600 seed per cultivar. Cultivar had a significant effect on the recovery of $C$. parasiticum $(C P)(F$ significant at $P=0.0001)$, on the number of seed that were speckled $(P=0.0001)$, and on the disease incidence in the field $(P=0.0001)$. Each genotype was analyzed separately: visual category had a significant effect on the ability to isolate CP ( $F$ value significant at $P=0.0001$ for all genotypes).

${ }^{\mathrm{b}}$ Proportion of seed of specified symptom with positive isolations of $C$. parasiticum $(\mathrm{CP})$. 
$\mathrm{cm}$ apart, and seed were hand planted through the holes in the black plastic. In 1993, 1994, and 1995, the black plastic was removed immediately prior to planting. Precision spacing of seed resulted from the combination of mechanical hole placement and hand planting. Immediately after planting, plots were mulched to $95 \%$ coverage with wheat straw (1.5 bales of wheat straw per plot). Mulching was in- tended to reduce soil temperature via shading and moisture conservation. Nitrogen was added by hand broadcasting ammonium nitrate $(67.2 \mathrm{~kg} / \mathrm{ha})$. Otherwise, the crop was grown using production practices recommended by the North Carolina Cooperative Extension Service (16).

Plots were planted with speckled or asymptomatic seed selected from commercial seed lots. Speckled seed were hand selected from two cultivars, NC 7 and NC $10 \mathrm{C}$, in each year. Asymptomatic seed were obtained from NC-V 11 (1992) or NC $7(1993,1994,1995)$ lots produced in an area at low risk for infection by $C$. parasiticum. Planting untreated asymptomatic seed of a susceptible cultivar served as an additional check for the presence of soilborne or windblown inoculum in the test area. Four hundred fifty-four grams of each

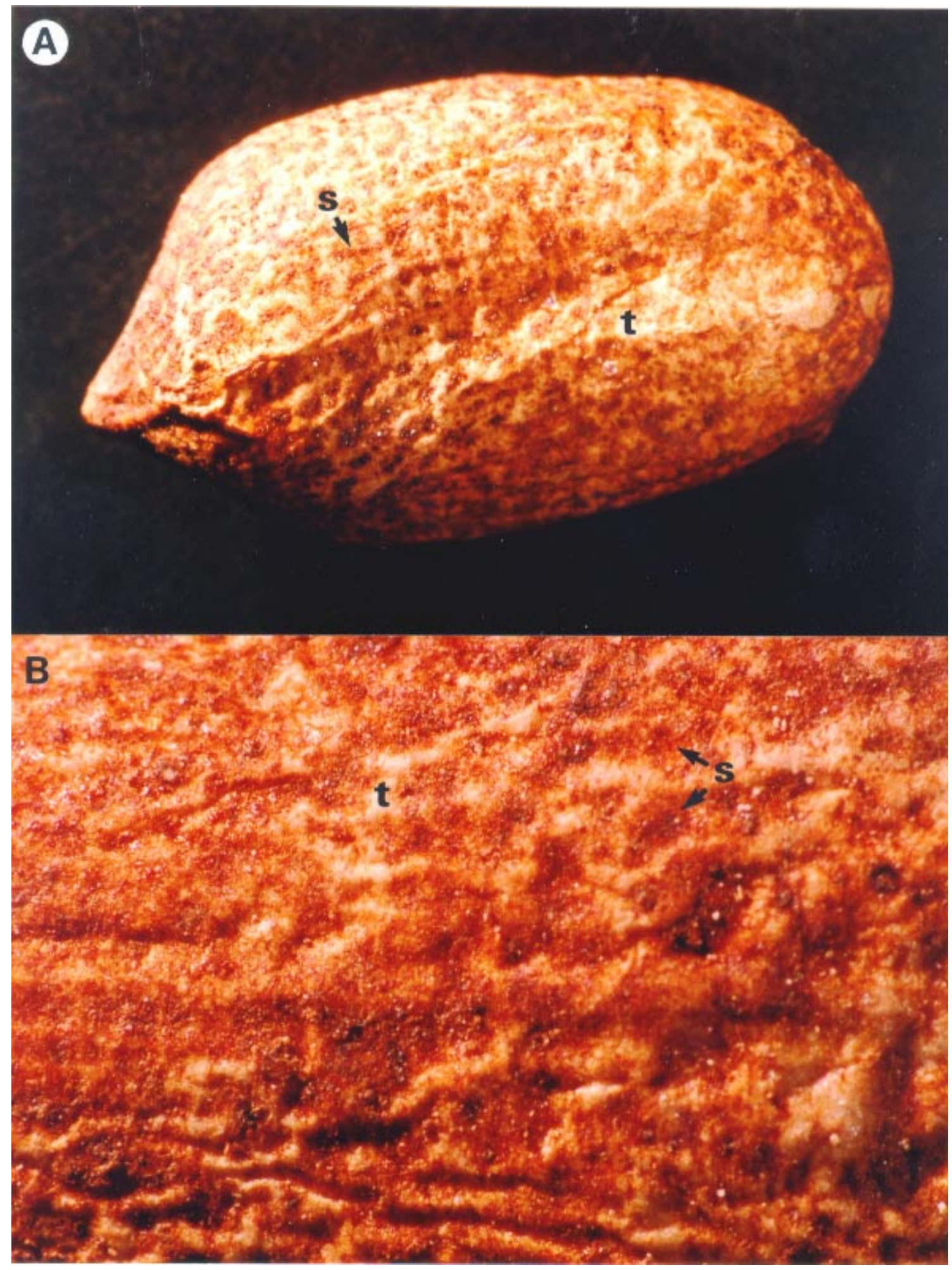

Fig. 1. Peanut seed with speckled testa symptomatic of colonization by Cylindrocladium parasiticum. A, Cinnamon brown speckles (s) surrounded by a lightened portion of testa $(t)$ on whole peanut. B, Enlarged portion of testal surface with speckles varying from cinnamon brown to very dark brown. 
lot were treated with the most commonly used seed treatment $(3.125 \mathrm{~g} / \mathrm{kg}$ of seed $)$ for Virginia-type peanuts (in 1992: captan + carboxin + dicloran [45:18:15\% of product, Gus 3-Way, Gustafson, Dallas, TX], and in 1993, 1994, 1995: captan + PCNB + carboxin [45:15:10\%, Vitavax PC, Gustafson,]) prior to planting. Nontreated seed served as controls. One hundred seed were planted per four replicate plots for each seed source (cultivar-seed symptom) by treatment (seed treated or not) combination. The number of seedlings that emerged was recorded 19 to 23 days after planting. Plants were checked weekly throughout the growing season for disease. Plants with symptoms and/or signs of CBR were removed, and the location was marked with a flag. Symptomatic tissue was selected from each plant, surface disinfested $(30 \mathrm{~s}$ in $0.52 \% \mathrm{NaOCl}$, drained; rinsed $30 \mathrm{~s}$ in sterile distilled water), and plated on a medium semi-selective for $C$. parasiticum (20). Presence of $C$. parasiticum was recorded for each plant after incubation for 7 days at room temperature under continuous fluorescent light. Proportion of seed transmission (rate) was calculated two ways. First, the rate was calculated based on the number of diseased plants per total number of speckled seed planted. Then, the rate was calculated based on the number of diseased plants per number of speckled seed that should have contained viable $C$. parasiticum based on isolation assays conducted at the time of planting. Proportion of seed transmission based both on number of seeds planted and on number of seeds expected to have viable inoculum was analyzed across the 4 years with a general linear model procedure (SAS Institute) by year and seed treatment. Direct statistical comparison between cultivars was not possible because not all combinations of cultivar $\times$ seed treatment $\times$ symptom were planted in each year.

An estimate of the number of diseased plants that would result per hectare, based on the transmission rates observed, was calculated for each treatment-seed source combination for each year using the formula: $D_{P}=N^{*} P^{*} R$ where $D_{P}=$ the projected disease incidence expressed as the number of diseased plants per hectare; $N=$ the number of seeds planted per hectare; $P$ $=$ the proportion of seed planted that were speckled; and $R=$ the seed transmission rate. Since the proportion of seed is also adjusted to account for seed with viable inoculum, the projected disease incidence for a given seed source is the same for both transmission rates.

A variation of the experiment was established in 1996. The planting pattern used the first 4 years was equivalent to 6 seeds per $0.9 \mathrm{~m}$, a very low planting rate for peanuts. The large spacing facilitated tracking each seed planted. Since Virginiatype peanuts are normally seeded at the rate of 9 to 12 seeds per $0.9 \mathrm{~m}$, seeding rate was added as another factor. The seeding rate was either 6 seeds or 12 seeds per 0.9 $\mathrm{m}$ and was accomplished by placing either one or two seeds per hole. The second seed in the two seeds per hole plots was always a treated, asymptomatic seed and was placed $2.5 \mathrm{~cm}$ away from the first seed. The same seed source-seed treatment combinations were planted as in previous studies. Symptomatic seed were obtained from two heavily infested commercial production fields in North Carolina. Seed of cultivar NC 7 were collected from a field in Bertie County, and seed of VA-C 92R were collected from a field in Chowan County. Seed were dried to $10 \%$ moisture at the Peanut Belt Research Station, Lewiston, NC, and stored at the seed storage facility of the North Carolina Foundation Seed Producers, Zebulon, NC. Asymptomatic controls were commercially produced seed (NC 7, Wakefield Peanut Co., Wakefield, VA). A general linear model procedure (SAS Institute) was used to determine if use of a seed treatment or seeding rate affected seed transmission.
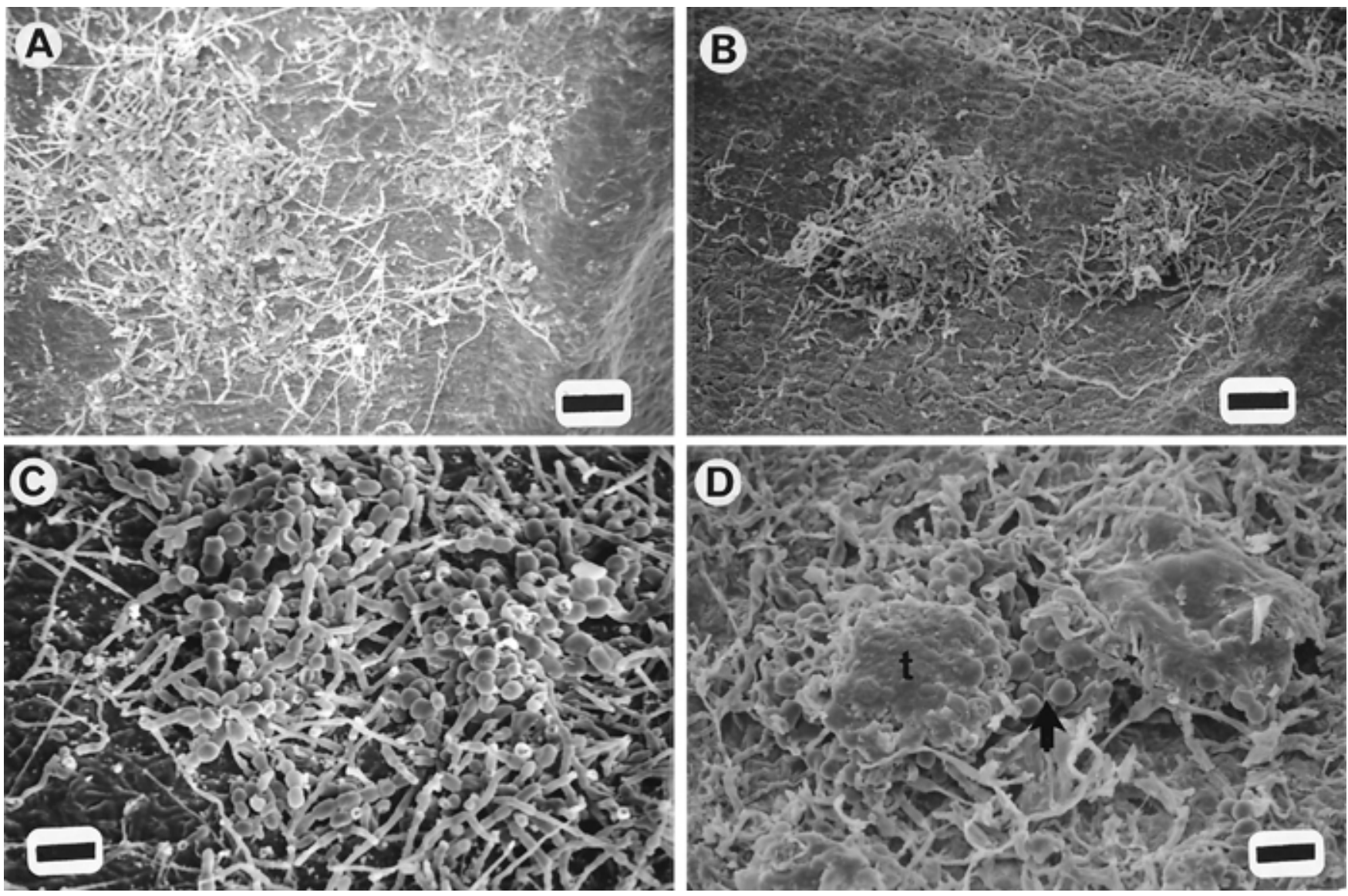

Fig. 2. Scanning electron micrographs of the surface of speckled peanut testa colonized by Cylindrocladium parasiticum. A and C, Testa of peanut fixed in glutaraldehyde immediately after digging, and $\mathbf{B}$ and D, testa of peanut fixed in glutaraldehyde after drying, storage, and shelling. A, Hyphae on surface of testa. Bar $=40 \mu \mathrm{m}$. B, Two microsclerotia covered with remnants of testa. Bar $=36 \mu \mathrm{m}$. C, Higher magnification of A. Bulbous nature of hyphae beginning to differentiate. Bar $=10 \mu \mathrm{m}$. D, Higher magnification of $\mathbf{B}$ with remnants of outer testa $(\mathrm{t})$ on top of a microsclerotium $(\operatorname{arrow})$. Bar $=10 \mu \mathrm{m}$. 


\section{RESULTS}

Symptomatology and pathogen isolations. Seed disinfestation did not affect recovery of $C$. parasiticum from seed ( $P=$ 0.2096). Therefore, all results are reported with the disinfestation (presence or absence) treatments combined.

The highest frequency of recovery of $C$. parasiticum was from speckled seed in all cultivars (Table 2). Other symptom categories with $>10 \%$ infected seed included vein and injured for NC 9 and light brown for NC-VII. Between 2 and $4 \%$ of asymptomatic seeds were infected with $C$. parasiticum (Table 2).

Cultivar significantly affected disease incidence in the field $(P=0.0001)$, the number of speckled seed $(P=0.0001)$, and recovery of $C$. parasiticum $(P=0.0001)$, with disease incidence and number of speckled seed being lowest in the resistant cultivar. Soil fumigation had no effect on percent recovery of $C$. parasiticum from seed, number of speckled seed, and disease incidence in the field. Fumigation and cultivar interactions did not occur $(P=$ 0.8515).

The characteristic symptom on speckled seeds (Fig. 1A and B) was cinnamon brown areas (speckles) interspersed in lighter areas across the surface of the testa. In cultivars with a pink testa, a desirable trait for Virginia-type peanuts, the testa was often tan between the cinnamon brown areas. The combination of the cinnamon brown speckles and the lighter than normal testae made these seeds very distinctive. The cinnamon brown speckles actually varied in color from "Cinnamon Brown" to "Russet" to "Mars Brown" (28). Colors in the lighter areas of the testa included "Pale Ochraceous Buff," "Light Vinaceous Cin- namon," and "Light Pinkish Cinnamon" (28).

Hyphae, globose modified hyphae, and/or microsclerotial initials were observed on the surface of the testa of speckled peanuts fixed in glutaraldehyde immediately after digging and after normal harvest and drying procedures (Fig. 2). The areas of hyphae and modified hyphae (microsclerotial initials) coincided with areas of cinnamon brown discoloration observed macroscopically on testae. The lighter areas coincided with either fungal activity within the middle layer of the testa without the fungus colonizing the surface of the testa or with the sloughing of the outer layer.

Three cellular regions were observed in the testa (Fig. 3): an outer single cell layer of thick-walled cells, which Porter et al. (23) referred to as sclerenchyma; a middle
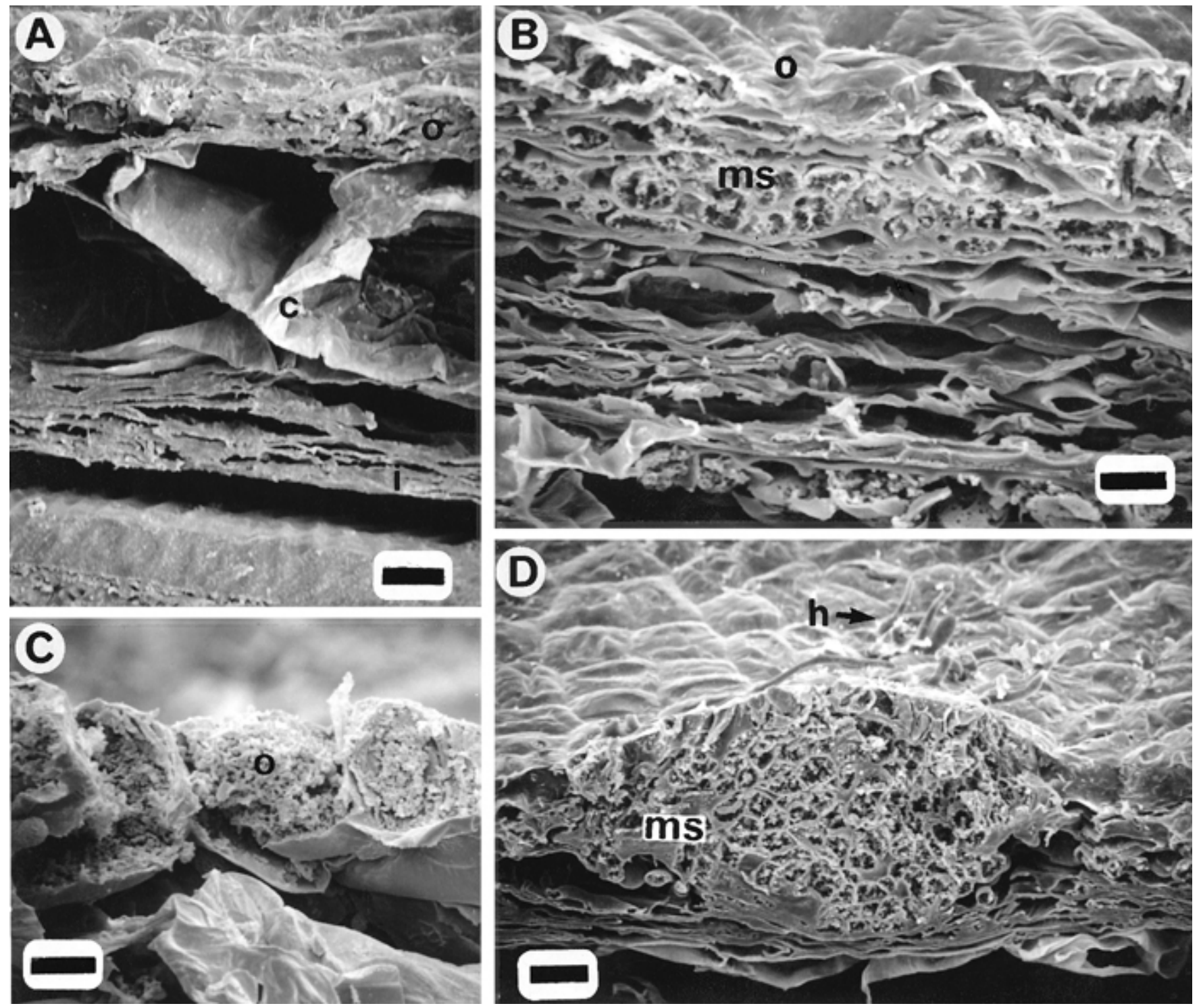

Fig. 3. Comparison of peanut testa colonized by Cylindrocladium parasiticum, B and D, with testa not colonized, A and C. A, Three layers are evident in testa not colonized by the pathogen: (o) the outer layer, one cell thick, with large cells; (c) the central (middle) region, multi-cells thick, with large areas with no cellular contents; and (i) the innermost layer, one cell thick and very thin in comparison to outer two layers. Bar $=20 \mu \mathrm{m}$. C, Outer layer of large cells. Bar $=10 \mu \mathrm{m}$. B and D, Testa colonized by pathogen with microsclerotium (ms) beneath outer layer, compressing middle cells. Bar $=20 \mu \mathrm{m}$ for $\mathbf{B}$. D, Outer layer can be penetrated by hyphae from below and is rarely observed to be thick-celled when areas above or below are colonized. Bar $=20 \mu \mathrm{m}$. 
multicellular layer of comparatively large cells that appeared devoid of cellular contents and through which fungal hyphae were often seen to ramify; and an inner single cell layer of thin-walled cells. Microsclerotia were observed within the middle area and varied from elongate (Fig. 3B) to globose (Fig. 3D). Hyphae emerged through the outer layer (Fig. 3D); hyphae and globose, modified hyphae formed on the surface of the testa (Figs. 2C, 3D, 4A and $\mathrm{B})$. Portions of the outer layer of the testa were sloughed off (Fig. 2D) or damaged (Fig. 4B and D). Hyphae and microsclerotia were observed in the region between the shell and the testa in freshly dug and preserved speckled peanuts (Fig. 4C).

Microsclerotia were produced in the testa, as reported previously by Porter et al. (23), and were similar to those described in spruce leaves by Bugbee and Anderson (4). They were larger than those reported in root cortex tissue by Johnston and Beute (12) and were similar to cells described as an infection cushion formed on the surface of the root (13).

Seed survey. Speckled seed were found in at least one subsample of each of the 62 commercial seed lots tested. The mean percentage of the seed with speckled testa was 1.28 with a range of 0.002 to 5.6. Twenty-eight percent of the sub- samples (34 of 120) had 10 or more speckled seed.

Seed transmission. Emergence of seedlings was affected by seed treatment $(P=$ $0.0001)$ and number of seed per locus $(P=$ 0.0001). Cultivar $\times$ seed treatment $(P=$ $0.0062)$ and seed treatment $\times$ seed-locus interactions $(P=0.0009)$ occurred with emergence. Seed treatment was a significant factor affecting total seed transmission $(P=0.00024)$, and there was a cultivar by seed treatment interaction. When the viability of the inoculum in the seed was taken into account, seed treatment was not significant. The only factor with a significant effect on seed transmission in the field tests conducted in 1992 through 1995 was year $(P=0.0047)$.

Seed were tested for viable $C$. parasiticum prior to or immediately following planting each year. $C$. parasiticum was not detected in the asymptomatic seed lots used as controls, and disease was never observed in plots planted with these seed (Table 3). Percentages of speckled seed with viable $C$. parasiticum in symptomatic seed lots at the time of planting ranged from 4 to $45 \%$ (Table 3). Plants infected with $C$. parasiticum as verified by isolation were found each year in at least one plot planted with nontreated speckled seed. Seed transmission rates based on number of seed planted varied across years and cultivars from 0.25 to $6.0 \%$. Diseased plants generally were detected in late summer; however, in 1993, most of the diseased plants were observed early in the season as seedling blight (Table 4). Seedling blight symptoms were consistent with those observed with seed transmission studies conducted in the greenhouse (B. L. Randall-Schadel and J. E. Bailey, unpublished). Disease was not detected on plants grown from asymptomatic seed. Seed transmission (Tables 3 and 5) occurred with fungicide-treated, speckled seed of both cultivars planted in 1993 and 1995 (NC 7 and NC 10C) and in 1996 (NC 7 and VA-C 92R). Seed transmission rates in plots where the disease was detected varied from 0.25 to $3.75 \%$ for treated speckled seed and from 0.25 to $6.0 \%$ for nontreated speckled seed. In 1995, seed transmission occurred in both treated and nontreated seed of NC 7 plots but only in treated NC $10 \mathrm{C}$ plots. The total seed transmission rate, based on the estimated number of seeds with viable inoculum, increased (Table 3) to $75 \%$ with nontreated seed and $37.5 \%$ with treated seed.

Virginia-type peanuts are commonly planted at the rate of $112.2 \mathrm{~kg} / \mathrm{ha}$ or higher (16). The average number of seed per kilogram is 1,101 for cultivar NC 7 and 1,322
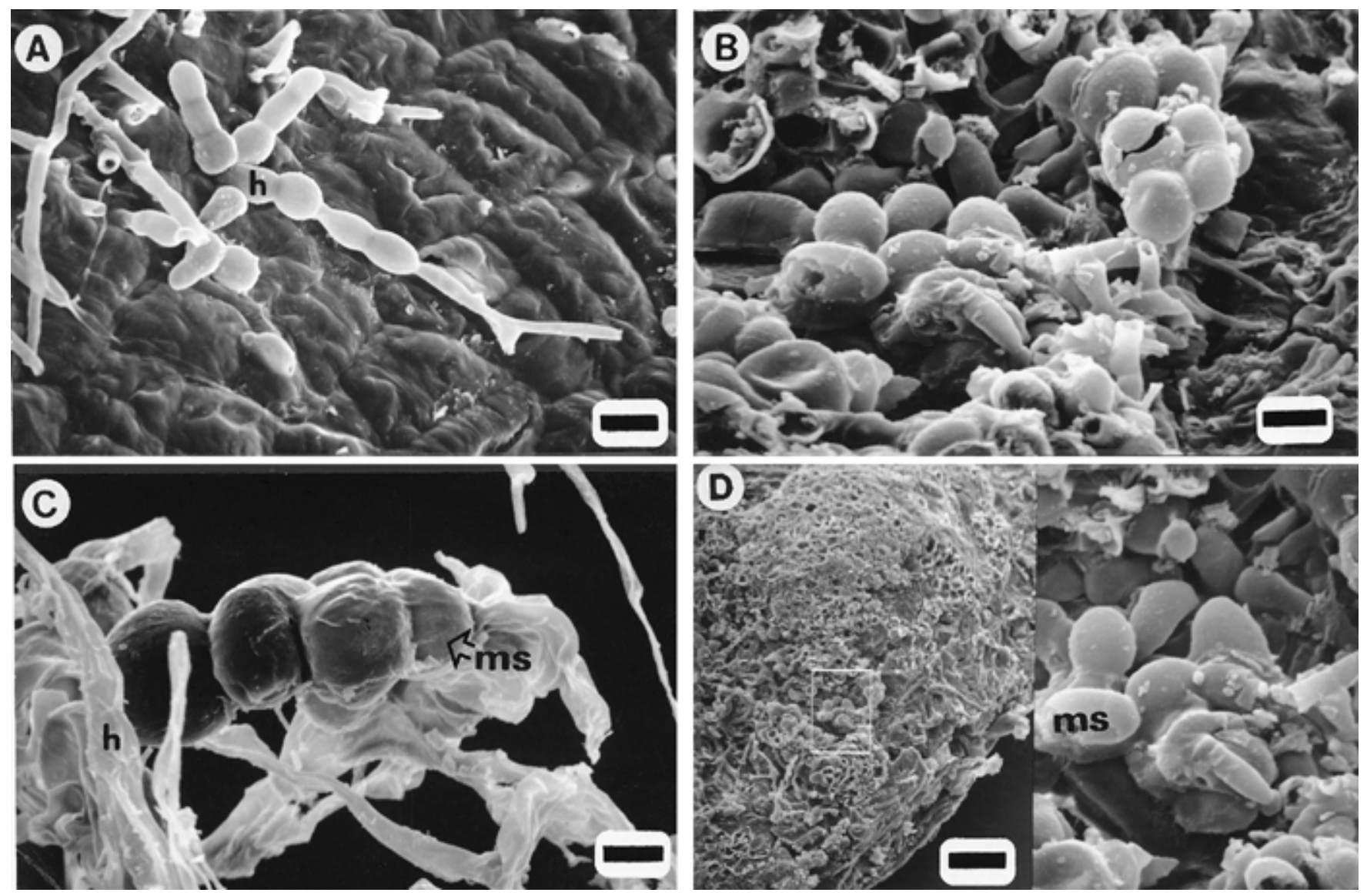

Fig. 4. Microsclerotia, hyphae, and modified hyphae formed by Cylindrocladium parasiticum in and on peanut testa. A, Hyphae (h) penetrating through outer testal layer from inside the testa and beginning to differentiate. Bar $=13 \mu \mathrm{m}$. B, Surface of microsclerotium in area where outer layer of testa has been sloughed. Bar $=8 \mu \mathrm{m}$. C, Microsclerotium (ms) formed among hyphae in space between testa and shell. Bar $=8.3 \mu \mathrm{m}$. D, Microsclerotium inside testa. $\mathrm{Bar}=40 \mu \mathrm{m}$ for image on left and $\mathrm{bar}=8 \mu \mathrm{m}$ for image on right. 
for NC 10C (16). Thus, 123,500 NC 7 seed would typically be planted per hectare $(N)$; 148,300 seed per hectare would be planted for NC 10C. The percentage of speckled seed in commercial seed lots found in the 1992 survey varied from almost 0.002 to $5.6 \%$ (mean $1.28 \%$ ), so the proportion of speckled seed $(P)$ ranged from 0.00002 to 0.056 (mean 0.0128). Transmission rates observed with treated seed (Table 3 ) varied from 0.25 to $3.75 \%$; the lowest rate with transmission observed was $0.25 \%$. Thus, a field planted with NC 7 seed could have 0 to 15 diseased plants per hectare (Table 6). Using the maximum seed transmission rates observed during this study with a single seed planted per locus, $6.0 \%$ for nontreated seed and $3.75 \%$ for treated seed, and using the maximum proportion of speckled seed observed in the commercial seed survey, the $D_{P}$ would be 445 and 231 diseased plants per hectare for nontreated and treated seed, respectively.

The rates of transmission observed in 1996 for single-seeded loci (Table 5) were within the ranges observed during the previous four seasons (Table 3). The rate of

Table 3. Seed transmission rates observed for Cylindrocladium parasiticum in peanuts planted in methyl bromide-fumigated raised beds in 1992 to 1995

\begin{tabular}{|c|c|c|c|c|c|c|c|}
\hline \multirow{3}{*}{\multicolumn{3}{|c|}{ Seed source $^{c}$}} & \multicolumn{5}{|c|}{ Seed transmission and inoculum viability ${ }^{a}$} \\
\hline & & & \multirow{3}{*}{$\begin{array}{c}\text { Viable } \\
\text { C. parasiticum } \\
\text { d }\end{array}$} & \multicolumn{2}{|c|}{ Nontreated seed } & \multicolumn{2}{|c|}{ Treated seed ${ }^{b}$} \\
\hline & & & & Total & Viable & Total & Viable \\
\hline Genotype & Symptom & Year & & transmission & transmission & transmission & transmission \\
\hline \multirow[t]{4}{*}{$\mathrm{NC} 7$} & Speckled & 1992 & 10 & 0.25 & 2.5 & 0 & 0 \\
\hline & & 1993 & 10 & 3.25 & 32.5 & 3.75 & 37.5 \\
\hline & & 1994 & 4 & 0 & 0 & 0 & 0 \\
\hline & & 1995 & 45 & 0.5 & 1.11 & 0.25 & 0.56 \\
\hline \multirow[t]{4}{*}{$\mathrm{NC} 10 \mathrm{C}$} & Speckled & 1992 & 15 & 0.25 & 3.5 & 0 & 0 \\
\hline & & 1993 & 8 & 6.0 & 75 & 0.5 & 6.25 \\
\hline & & 1994 & 6 & 0.25 & 4.17 & 0 & 0 \\
\hline & & 1995 & 15 & 0 & 0 & 0.25 & 1.67 \\
\hline
\end{tabular}

${ }^{a}$ Seed transmission rates are based on the data from four plots with 100 loci each. Loci were punched through black plastic that covered raised, methyl bromide-fumigated beds. Plastic was removed (except for 1992) and one seed planted in each locus. No diseased plants were detected in asymptomatic check plots.

${ }^{\mathrm{b}}$ Seed were treated with $3.1 \mathrm{~g} / \mathrm{kg}$ of seed of a treatment containing captan 45\%, carboxin 18\%, dicloran 15\% (1992; Gus 3-Way, Gustafson, Dallas, TX) or captan 45\%, PCNB 15\%, carboxin 10\% (1993, 1994, 1995; Vitavax PC, Gustafson).

${ }^{\mathrm{c}}$ Source of asymptomatic seed: 1992, 1993, 1995, Virginia; 1994, Texas. Cultivar of asymptomatic seed: 1992, NC V11; 1993 to 1995, NC 7. Source of symptomatic seed: 1992 to 1995, commercial seed conditioners in Virginia-Carolina region.

${ }^{\mathrm{d}}$ Evaluation factors: viable $C$. parasiticum $=$ number of seed with viable inoculum $=($ no. seed with viable $C$. parasiticum $/$ no. seed planted $) \times 100$ (determined by placing speckled seed in Cylindrocladium black rot medium at time of planting); total transmission $=($ no. diseased plants/no. loci with seed planted $) \times 100$; and viable transmission $=$ (no. diseased plants/expected no. of seed with viable inoculum $) \times 100$.

Table 4. Percentage of plants displaying symptoms of Cylindrocladium black rot from symptomatic peanut seed grown in methyl bromide-fumigated beds in 1993

\begin{tabular}{|c|c|c|c|c|c|c|c|}
\hline & & \multicolumn{6}{|c|}{ Seed transmission $(\%)^{\mathrm{a}}$} \\
\hline \multicolumn{2}{|c|}{ Seed source ${ }^{b}$} & \multicolumn{3}{|c|}{ Nontreated seed } & \multicolumn{3}{|c|}{ Treated seed } \\
\hline Genotype & Symptom & Before $6 / 27$ & After 8/1 & Total & Before $6 / 27$ & After 8/1 & Total \\
\hline NC 7 & Speckled & 2.75 & 0.5 & 3.25 & 1.25 & 2.5 & 3.75 \\
\hline $\mathrm{NC} 10 \mathrm{C}$ & Speckled & 6.0 & 0 & 6.0 & 0.25 & 0.25 & 0.5 \\
\hline NC 7 & Asymptomatic & 0 & 0 & 0 & 0 & 0 & 0 \\
\hline
\end{tabular}

a Percent seed transmission $=$ (no. diseased plants $/ 400$ seed planted $) \times 100$.

${ }^{\mathrm{b}}$ Source of asymptomatic seed: NC 7 seed commercially produced in Virginia. Source of symptomatic seed: commercial seed conditioner in VirginiaCarolina region.

Table 5. Seed transmission rates observed for Cylindrocladium parasiticum in peanuts planted at two seeding densities based either on total number of loci or on percentage of seed planted that would be expected to contain viable $C$. parasiticum as determined by laboratory isolations of seed from same source

\begin{tabular}{|c|c|c|c|c|c|c|c|c|c|c|}
\hline & & & \multicolumn{8}{|c|}{ Percent seed transmission $^{\mathrm{a}}$} \\
\hline & & & \multicolumn{4}{|c|}{ Nontreated seed } & \multicolumn{4}{|c|}{ Treated seed $^{\mathrm{b}}$} \\
\hline \multicolumn{3}{|c|}{ Seed source ${ }^{c}$} & \multicolumn{2}{|c|}{ One seed/locus } & \multicolumn{2}{|c|}{ Two seed/locus } & \multicolumn{2}{|c|}{ One seed/locus } & \multicolumn{2}{|c|}{ Two seed/locus } \\
\hline Genotype & Symptom & CP viability ${ }^{d}$ & Total & Viable & Total & Viable & Total & Viable & Total & Viable \\
\hline $\mathrm{NC} 7$ & Speckled & 22 & 1.5 & 6.8 & 5 & 22.7 & 1.25 & 5.7 & 7.0 & 31.8 \\
\hline VAC 92R & Speckled & 7 & 0.5 & 7.1 & 3.5 & 50.0 & 0.5 & 7.1 & 1.0 & 14.3 \\
\hline $\mathrm{NC} 7$ & $\begin{array}{l}\text { Asympto- } \\
\text { matic }\end{array}$ & 0 & 0 & 0 & 0 & 0 & 0 & 0 & 0 & 0 \\
\hline \multicolumn{11}{|c|}{$\begin{array}{l}\text { Seed transmission rates are based on data from four replications with } 100 \text { loci each. Loci were punched through plastic that covered raised, methyl bro- } \\
\text { mide-fumigated beds. Plastic was removed and one or two seed planted in each locus. In single-seeded plots, only seed with a given genotype-seed } \\
\text { treatment combination was planted at each locus. In double-seeded plots, two seeds were planted } 2.5 \mathrm{~cm} \text { apart: one seed of the given genotype-seed } \\
\text { treatment and one an asymptomatic, treated NC } 7 \text { seed. Total seed planted }=(\text { no. diseased plants } / \text { no. loci with seed planted) } \times 100 \text {. Seed with viable CP }= \\
\text { viability transmission rate }=\text { (no. diseased plants } / \text { expected no. of seed with viable inoculum) } \times 100 \text {. } \\
\text { b Seed were treated with } 3.1 \mathrm{~g} / \mathrm{kg} \text { of seed of a treatment containing captan } 45 \%, \text { PCNB } 15 \% \text {, carboxin } 10 \% \text { (Vitavax PC, Gustafson, Dallas. TX). }\end{array}$} \\
\hline \multicolumn{11}{|c|}{$\begin{array}{l}{ }^{\mathrm{c}} \text { Speckled seed harvested in } 1996 \text { from peanut production fields heavily infested with } C \text {. parasiticum. NC } 7 \text { seed were harvested from a field in Berti } \\
\text { County, NC, and VaC92R seed were harvested from Chowan County, NC. Asymptomatic seed were purchased from commercial seed dealer. Asympto } \\
\text { matic seed were not used in analysis. }\end{array}$} \\
\hline
\end{tabular}


seed transmission of $C$. parasiticum based on the number of symptomatic seed planted was significantly higher $(P=$ 0.0049 ) for $\mathrm{NC} 7$ than for VA-C 92R (Table 5). However, when the transmission rate was adjusted to account for the proportion of the seed having viable $C$. parasiticum, the one seed per locus rates were not significantly different between cultivars (Table 5).

Seed transmission was affected by the seeding pattern $(P=0.0073)$. Transmission rates in plots with double-seeded loci were two to seven times higher than those observed in plots with single-seeded loci (Table 5). More diseased plants were observed in plots with loci double-seeded with cultivar NC 7 than with VA-C 92R, as expected since more of the NC 7 seed contained viable $C$. parasiticum (22\%) than did the VA-C $92 \mathrm{R}$ seed $(7 \%)$. The difference between single- and doubleseeding the loci increased when the seed transmission rate was adjusted for the effect of inoculum viability $(P=0.0019)$. Adjacent plants were observed to be diseased in only one plot with single-seeded loci. However, adjacent plants were observed to be diseased in nine plots with double-seeded loci. In three plots of double-seeded loci, diseased plants were observed at adjacent loci (clusters) more than once within the plot. Disease was not detected in plots where only asymptomatic seed were planted.

\section{DISCUSSION}

Seed transmission by $C$. parasiticum had been speculated but not confirmed until this study. The low rates of seed transmission observed using speckled seed suggest the difficulty previous workers would have encountered using seed not selected for obvious infection by the pathogen. Visual assessments and isolation of $C$. parasiticum, although confirming work by others $(21,23)$, further indicated the recovery of this pathogen was related to specific symptom category. The pathogen was isolated from seed with the various categories of testal symptoms and from asymptomatic seed. This indicates that removal of all discolored seed would further reduce the risk of seed transmission. Inoculum could still be present after the removal of symptomatic seed, however, since C. parasiticum can be isolated from asymptomatic seed produced in an infested field.

The proportion of speckled seed found in metam sodium-fumigated plots was not significantly different from that found in nonfumigated plots. Metam sodium application provides a $\mathrm{V}$-shaped zone of reduced inoculum into which the seed are planted (5). This zone allows most of the taproot and many of the lateral roots, pegs, and pods to avoid contact with the pathogen $(1,2,5)$. The metam sodium rates applied for peanut production do not eradicate the pathogen, and toxic effects of this biocide are diminished at or near the soil surface. Therefore, metam sodium-fumigated fields may appear to be uninfested by $C$. parasiticum. Inoculum can be added into the fumigated zone by planting symptomatic seed or by reintroduction of infested soil during planting. Since only the V-shaped zone receives the fumigant, plants peg into soil where populations of $C$. parasiticum were not reduced. Pod and seed infections can occur without obvious aboveground symptoms. Hollowell et al. (10) isolated $C$. parasiticum frequently from pods during a pod rot survey despite attempts to avoid plants with symptoms of this disease. The lack of a significant fumigation effect on the proportion of speckled seed may also be a result of differential resistance to the pathogen for root and pod infections among cultivars used in this study, as indicated for some cultivars by Coffelt and Garren (6). However, there was a noticeable effect by cultivar on disease incidence, percentage of speckled seed, and recovery of the pathogen. The moderately resistant cultivar NC 10C had both lower levels of disease incidence and speckled seed percentages. The effect of cultivar on recovery may be an indication more of the number of speckled seed than on the ability to recover the pathogen from speckled seed.

Factors anticipated to affect seed transmission in the field trials, seed treatment and cultivar, did not affect seed transmission based on total symptomatic seed planted. Seed treatment did affect seed transmission when the viability of the inoculum in the seed was used in the calculation of seed transmission. Seed treatment, however, was not consistently effective in controlling seed transmission. Year significantly affected seed transmission, and this effect may be related to environmental factors affecting either the production of the speckled seed or the conditions of the field trials. CBR is affected by factors such as soil moisture and temperature $(17,19,33,34)$ and inoculum density $(18,21)$. The effect on the amount of inoculum in a given seed has not been examined and may contribute to the variability observed.

Calculations of predicted disease incidence indicated that seed transmission of C. parasiticum could add from 15 to 231 disease foci per hectare from commercially treated seed. The inoculum produced in these foci can affect fields with no previous history of CBR at great distances from the seed's source. Randall-Schadel et al. (26) found that inoculum in a single focus in a single year could infect one plant and spread to the plants whose pegs, pods, and roots grow into that focus. Inoculum was spread up to $10 \mathrm{~m}$ in the second year of continuously cropped peanuts. It would be easy to overlook a few diseased plants in a hectare of peanut plants. Seedling blight can be especially difficult to detect, since symptoms are similar to those of Aspergillus crown rot and other seedling diseases. Simultaneous infection by other soilborne pathogens also can complicate the detection of CBR. Secondary spread from infected seed or diseased seedlings could result in a substantial increase in colonized plants and subsequent increase in inoculum that may or may not be accompanied by detectable symptoms or signs. Low seed transmission rates coupled with the potential for inoculum to build up in subsequent crops could explain why Rowe and colleagues (30) were not able to relate disease incidence to seed transmission.

Peanuts are usually seeded at three to four seeds per $0.9 \mathrm{~m}$. It is common for more than one seed to fall at a given loca-

Table 6. Predicted number of diseased peanut plants possible from seed transmission of Cylindrocladium parasiticum based on seed transmission rates observed in the field in 1992 to 1995 (Table 4), on 123,400 seed planted per hectare, and on the maximum and mean proportion of speckled seed found in a 1993 survey of 62 commercial seed lots of Virginia-type peanuts

\begin{tabular}{|c|c|c|c|c|c|c|c|c|c|}
\hline \multirow{3}{*}{$\begin{array}{l}\text { Proportion of } \\
\text { speckled seed }\end{array}$} & \multirow[b]{3}{*}{ Genotype } & \multicolumn{8}{|c|}{ Predicted disease incidence (plants/ha) ${ }^{\mathrm{a}}$} \\
\hline & & \multicolumn{4}{|c|}{ Nontreated seed } & \multicolumn{4}{|c|}{ Treated seed } \\
\hline & & 1992 & 1993 & 1994 & 1995 & 1992 & 1993 & 1994 & 1995 \\
\hline 0.05 & $\mathrm{NC} 7$ & 15 & 200 & 0 & 31 & 0 & 231 & 0 & 15 \\
\hline (maximum) & $\mathrm{NC} 10 \mathrm{C}$ & 19 & 445 & 19 & 0 & 0 & 37 & 0 & 19 \\
\hline 0.0128 & NC 7 & 4 & 51 & 0 & 8 & 0 & 59 & 0 & 4 \\
\hline (mean) & $\mathrm{NC} 10 \mathrm{C}$ & 5 & 114 & 5 & 0 & 0 & 9 & 0 & 5 \\
\hline
\end{tabular}

${ }^{\text {a }}$ Proportions of speckled seed based on visual and weight analysis of 62 seed lots (two 500-g subsamples for each seed lot) of commercial Virginia-type peanuts. The maximum proportion of speckled seed observed was 0.05 and the mean was 0.0128 .

${ }^{\mathrm{b}}$ Predicted disease incidence $=$ seed $/ \mathrm{ha}[123,500$ for NC $7(112.2 \mathrm{~kg} \mathrm{seed} / \mathrm{ha} \times 1,101 \mathrm{seed} / \mathrm{kg}) ; 148,300$ for NC $10 \mathrm{C}(112.2 \mathrm{~kg} \mathrm{seed} / \mathrm{ha} \times 1,322 \mathrm{seed} / \mathrm{kg})] \times$ proportion of speckled seed found in 1993 survey (average or maximum) $\times$ proportion of seed transmission (total transmission rate/100) (Table 3) and rounded to the nearest whole number. 
tion, resulting in seed planted in close proximity. The results from the singleversus double-seeded loci indicated that proximity of plants is a factor increasing seed transmission. Randall-Schadel et al. (27) found that $C$. parasiticum infection negatively affects both the germination and the vigor of symptomatic seed. Heavily infected seed, especially in cool moist springs, would be at a higher risk not to germinate, and high seeding rates would increase the likelihood of another plant sending roots or pegs in contact with soil or plant material infested with $C$. parasiticum originating from speckled seed. This may have accounted for the seedling blight observed in 1993.

This study indicates seed transmission occurs with treated seed. Although cultivars differ in susceptibility to this pathogen in root, pod, and seed infections, they do not differ in the ability of symptomatic seed to transmit the disease. Research is needed to confirm that the location of the fungus in the seed affects the sensitivity of the fungus to seed treatments and to conditions occurring during drying, storage, and conditioning. Research is also needed to determine if other factors are involved in protecting the fungus, such as some type of dormancy or fungicideinduced stasis that may allow the fungus to survive the treatments and cause infection once the toxic effects have subsided. Other seed treatments need to be screened for efficacy.

Porter and Mozingo (22), Porter et al. (23), and Randall-Schadel et al. (25) have suggested that symptomatic seed can be removed by optical sorting methods. Current cleaning and sorting regimes, which include optical scanning, are not removing the speckled seed, as indicated by the 1992 survey and the selection of speckled seed from commercial conditioned bins in 1992 through 1995 for the field studies. Removing the speckled seed would be a loss of peanut seed, but Mozingo et al. (15) reported the flavor components of speckled seed are comparable to or better than those of asymptomatic seed from the same seed source. Therefore, the speckled seed could be used in the edible market where splits and bald heads (no testa present) removed during cleaning peanut seed currently are used.

Peanut seed producers and conditioners should work with plant pathologists, agronomists, and certification agencies to develop a strategy to reduce levels of $C$. parasiticum in the peanut seed trade. Improved field practices, such as field selection, soil assays, fumigation, and scouting are needed. Improvements in seed cleaning and sorting practices, such as more effective optical sorting, monitoring of viable inoculum in storage, and the evaluation of new seed treatments, are underway. Improvement in these areas in combination with improved quality testing such as seed health assays should reduce if not eliminate seedborne inoculum.

\section{ACKNOWLEDGMENTS}

We thank Barbara Shew and Marcia Gumphertz for statistical advice, Joyce Hollowell and Kathy Williams for technical support in the field and laboratory, William Schadel for technical assistance with the scanning electron microscopy, and William Cline and the staff of the Horticultural Crops Research Station, Castle Hayne, NC, for help establishing, maintaining, and harvesting field plots. Financial support was provided in part by the Everett Byrd Foundation, the North Carolina Peanut Growers Association, and Peanut CRSP USAID grant LAG-G-00-96-90013-00.

\section{LITERATURE CITED}

1. Bailey, J. E. 1991. Peanut disease control: CBR management. North Carolina State University. Plant Disease Information Note No. 2.

2. Bailey, J. E., and Maytac, C. A. 1989. A decision model for use of fumigation and resistance to control Cylindrocladium black rot of peanuts. Plant Dis. 73:323-326.

3. Bell, D. K., and Sobers, E. K. 1966. A peg, pod and root necrosis of peanuts caused by a species of Calonectria. Phytopathology 56:1361-1364.

4. Bugbee, W. M., and Anderson, N. A. 1963. Infection of spruce seedlings by Cylindrocladium scoparium. Phytopathology 53:11281132.

5. Cline, W. O., and Beute, M. K. 1986. Effect of metam sodium, peanut cultivar and inoculum density on incidence of Cylindrocladium black rot. Peanut Sci. 13:41-45.

6. Coffelt, T. A., and Garren, K. H. 1982. Screening for resistance to Cylindrocladium black rot in peanuts. Peanut Sci. 9:1-5.

7. Garren, K. H., Beute, M. K., and Porter, D. M. 1972. The Cylindrocladium black rot of peanut in Virginia and North Carolina. J. Am. Peanut Res. Educ. Assoc. 4:67-71.

8. Garren, K. H., and Porter, D. M. 1970. Quiescent endocarpic floral communities in cured mature peanuts. Phytopathology 60:16351638.

9. Hiller, R. B. 1975. The role of birds in spreading the Cylindrocladium black rot of peanuts. M.S. thesis. Virginia Polytechnic Institute and State University, Blacksburg.

10. Hollowell, J. E., Shew, B. B., Beute, M. K., and Abad, Z. G. 1998. Occurrence of pod rot pathogens in peanuts grown in North Carolina. Plant Dis. 82:1345-1349.

11. Johnson, G. I. 1985. Occurrence of Cylindrocladium crotalariae on peanut (Arachis hypogaea) seed. Plant Dis. 69:434-436.

12. Johnston, S. A., and Beute, M. K. 1975. Histopathology of Cylindrocladium black rot in peanut. Phytopathology 65:649-653.

13. Krigsvold, D. R., Garren, K. H., and Griffin, G. J. 1977. Importance of field cultivation and soybean cropping in the spread of Cylindrocladium crotalariae within and among peanut fields. Plant Dis. Rep. 61:495-499.

14. Misonou, T. 1973. New black rot disease in soybeans and peanuts caused by Calonectria crotalariae. Shokubutsu Boeki 27:35-40.

15. Mozingo, R. W., Young, C. T., and Porter, D. M. 1995. Headspace analysis and fatty acid composition of peanut seed from CBR infested fields. (Abstr.) Proc. Am. Peanut Res. Educ. Soc. 27:47.

16. North Carolina Extension Service. 1993. 1993 Peanut Information. North Carolina State University, N.C. Ext. Serv. AG-331.

17. Pataky, J. K., and Beute, M. K. 1983. Effects of inoculum burial, temperature, and soil moisture on survival of Cylindrocladium crotalariae microsclerotia in North Carolina. Plant Dis. 67:1379-1382.

18. Phipps, P. M., and Beute, M. K. 1977. Sensitivity of susceptible and resistant peanut cultivars to inoculum densities of Cylindrocladium crotalariae microsclerotia in soil. Plant Dis. Rep. 61:300-303.

19. Phipps, P. M., and Beute, M. K. 1979. Population dynamics of Cylindrocladium crotalariae microsclerotia in naturally-infested soil. Phytopathology 69:240-243.

20. Phipps, P. M., Beute, M. K., and Barker, K. R. 1976. An elutriation method for quantitative isolation of Cylindrocladium crotalariae microsclerotia from peanut field soil. Phytopathology 66:1255-1259.

21. Porter, D. M., and Mozingo, R. W. 1986 Importance of seed transmission in the spread of Cylindrocladium crotalariae. Peanut Sci 13:80-82.

22. Porter, D. M., and Mozingo, R. W. 1991. Peanut seed testa discoloration and microsclerotial populations as related to field incidence of Cylindrocladium black rot. (Abstr.) Proc. Am. Peanut Res. Educ. Soc. 23:51.

23. Porter, D. M., Wright, F. S., Taber, R. A., and Smith, D. H. 1991. Colonization of peanut seed by Cylindrocladium crotalariae. Phytopathology 81:896-900.

24. Randall-Schadel, B. L. 1999. Seed transmission of Cylindrocladium parasiticum in peanut (Arachis hypogaea L.). Ph.D. diss. North Carolina State University, Raleigh.

25. Randall-Schadel, B. L., Bailey, J. E., and Dowell, F. E. 1992. Relationship between symptoms on testae of peanut (Arachis hypogaea) and isolation of Cylindrocladium crotalariae. (Abstr.) Phytopathology 82:1072.

26. Randall-Schadel, B. L., Bailey, J. E., Shew, B. B., and Beute, M. K. 1996. Establishment of Cylindrocladium parasiticum in a noninfested peanut field. (Abstr.) Phytopathology 86:S42.

27. Randall-Schadel, B. L., Bailey, J. E., and Spears, J. F. 1996. Effect of storage duration on seed quality and viability of Cylindrocladium parasiticum in peanut seed. (Abstr.) Proc. Am. Peanut Res. Educ. Soc. 28:54.

28. Ridgeway, R. 1912. Color Standards and Color Nomenclature. Published by Author, Washington, DC.

29. Rodriquez-Kabana, R., Backman, P. A., and Farrar, L. L. 1974. Occurrence and control of Cylindrocladium crotalariae in peanut field in Alabama. (Abstr.) Proc. Am. Peanut Res. Educ. Assoc. 5:64

30. Rowe, R. C., Beute, M. K., and Wells, J. C. 1973. Cylindrocladium black rot of peanuts in North Carolina, 1972. Plant Dis. Rep. 57:387389.

31. Rowe, R. C., Johnston, S. A., and Beute, M. K. 1974. Formation and dispersal of Cylindrocladium crotalariae microsclerotia in infected peanut roots. Phytopathology 64:12941297.

32. Sharma, N. D., Vyas, S. C., and Jain, A. C. 1978. A groundnut disease new to India. Sci. Cult. 44:119-120.

33. Sidebottom, J. R., and Beute, M. K. 1989. Control of Cylindrocladium black rot of peanut with cultural practices that modify soil temperature. Plant Dis. 73:672-676.

34. Taylor, J. D., Griffin, G. J., and Garren, K. H. 1981. Inoculum pattern, inoculum densitydisease incidence relationships, and population fluctuations of Cylindrocladium crotalariae microsclerotia in peanut field soil Phytopathology 71:1297-1302.

35. Young, C. T., and Schadel, W. E. 1989. A method for light and scanning electron microscopy of drought induced damage of resting peanut seed tissue. Food Microstructure 8:253-256. 